\title{
Results of the 1997 Golden-cheeked Warbler and Black-capped Vireo Monitoring Program on Camp Bullis, Texas
}

by

Howard J. Weinberg

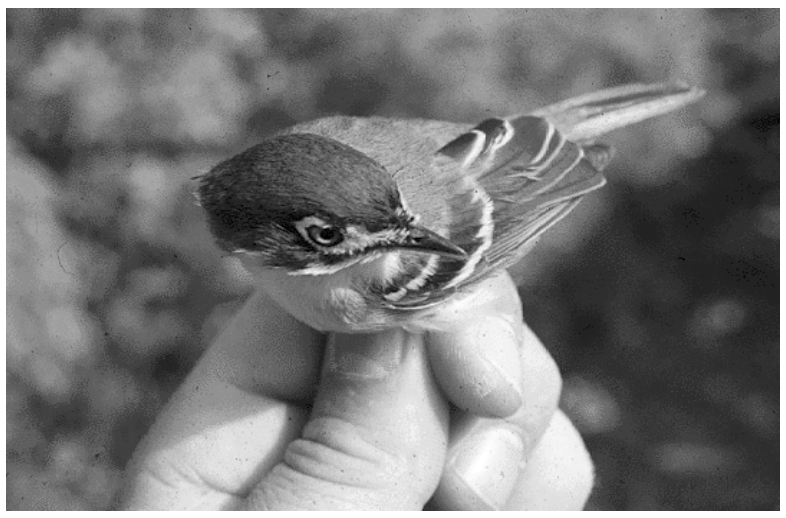

The Golden-cheeked Warbler (Dendroica chrysoparia) and Black-capped Vireo (Vireo atricapillus) are endangered migratory songbirds that nest on Camp Bullis, Texas. The warbler has been censused each year since 1991. Data has been collected on the vireo since 1989. This report discusses the results of the 1997 field season. This information can be used by training managers to ensure success of the training mission while complying with the Endangered Species Act.

Results suggest that the 1997 warbler population was relatively stable, based on point counts, surveys, and estimates of density. Warblers were detected on 66.7 percent of the survey lines; the installation-wide density estimate was
.076 birds per hectare compared to an overall density of .071 (1991 to 1997).

The number of Black-capped Vireos detected on the installation rose from 6 in 1996 to 12 in 1997. Historically, approximately 11 male vireos were detected annually from 1989 to 1997 . Most vireos found in 1997 were at sites that have housed vireos in the past. Some vireos were also found in new areas (e.g., Spoffard Hill) while some traditional sites (e.g., Sykes Hill) were not occupied in 1997.

This report also presents recommendations addressing monitoring needs and future research. 
Public reporting burden for this collection of information is estimated to average 1 hour per response, including the time for reviewing instructions, searching existing data sources, gathering and maintaining the data needed, and completing and reviewing the collection of information. Send comments regarding this burden estimate or any other aspect of this collection of information, including suggestions for reducing this burden, to Washington Headquarters Services, Directorate for information Operations and Reports, 1215 Jefferson Davis Highway, Suite 1204, Arlington, VA 22202-4302, and to the Office of Management and Budget, Paperwork Reduction Project (0704-0188), Washington, DC 20503.

\begin{tabular}{|l|l|l|}
\hline 1. AGENCY USE ONLY (Laave Blank) & $\begin{array}{c}\text { 2. REPORT DATE } \\
\text { April } 1998\end{array}$ & $\begin{array}{c}\text { 3. REPORT TYPE AND DATES COVERED } \\
\text { Final }\end{array}$
\end{tabular}

4. TITLE AND SUBTITLE

Results of the 1997 Golden-cheeked Warbler and Black-capped Vireo Monitoring

5. FUNDING NUMBERS

Program on Camp Bullis, Texas

MIPR

7FCEIED083

6. AUTHOR(S)

Howard J. Weinberg

7. PERFORMING ORGANIZATION NAME(S) AND ADDRESS(ES)

U.S. Army Construction Engineering Research Laboratories (USACERL)

P.O. Box 9005

Champaign, II 61826-9005

8. PERFORMING ORGANIZATION

REPORT NUMBER

TR $98 / 61$

9. SPONSORING / MONITORING AGENCY NAME(S) AND ADDRESS(ES)

Fort Sam Houston and Camp Bullis

10. SPONSORING / MONITORING

AGENCY REPORT NUMBER

ATTN: MGCA-PW-ENR

Building 4196

Fort Sam Houston, TX 78234

\section{SUPPLEMENTARY NOTES}

Copies are available from the National Technical Information Service, 5285 Port Royal Road, Springfield, VA 22161.

12a. DISTRIBUTION / AVAILABILITY STATEMENT

12b. DISTRIBUTION CODE

Approved for public release; distribution is unlimited.

13. ABSTRACT (Maximum 200 words)

The Golden-cheeked Warbler (Dendroica chrysoparia) and Black-capped Vireo (Vireo atricapillus) are endangered migratory songbirds that nest on Camp Bullis, Texas. The warbler has been censused each year since 1991. Data has been collected on the vireo since 1989. This report discusses the results of the 1997 field season. This information can be used by training managers to ensure success of the training mission while complying with the Endangered Species Act. Results suggest that the 1997 warbler population was relatively stable, based on point counts, surveys, and estimates of density. Warblers were detected on 66.7 percent of the survey lines; the installation-wide density estimate was .076 birds per hectare compared to an overall density of .071 (1991 to 1997). The number of Black-capped Vireos detected on the installation rose from 6 in 1996 to 12 in 1997 . Historically, approximately 11 male vireos were detected annually from 1989 to 1997 . Most vireos found in 1997 were at sites that have housed vireos in the past. Some vireos were also found in new areas (e.g., Spoffard Hill) while some traditional sites (e.g., Sykes Hill) were not occupied in 1997. This report also presents recommendations addressing monitoring needs and future research.

14. SUBJECT TERMS Golden-cheeked Warbler

Black-capped Vireo

Camp Bullis, TX

endangered species

bird populations

natural resource management
17. SECURITY CLASSIFICATION OF REPORT Unclassified

18. SECURITY CLASSIFICATION
OF THIS PAGE
Unclassified

Unclassified
9. SECURITY CLASSIFICATION OF ABSTRACT Unclassified

15. NUMBER OF PAGES 40

16. PRICE CODE

20. LIMITATION OF ABSTRACT

SAR 


\section{Foreword}

This study was conducted for Fort Sam Houston and Camp Bullis, Texas, under MIPR 7FCEIED083, "1997 Field Season Report: Results of the 1997 Goldencheeked Warbler and Black-capped Vireo Monitoring Program on Camp Bullis, Texas.” The technical monitor was Ms. Jackie Schlatter, MGCA-PW-ENR.

The work was performed by the Natural Resources Assessment and Management Division (LL-N), U.S. Army Construction Engineering Research Laboratories (USACERL) in cooperation with Fort Sam Houston, Camp Bullis, and the Center for Ecological Management of Military Lands (CEMML) of Colorado State University. The USACERL Principal Investigator was Timothy J. Hayden. This report was prepared by Howard J. Weinberg of CEMML. Dr. William D. Severinghaus is Operations Chief, CECER-LL. The USACERL technical editor was Gloria J. Wienke, Technical Information Team.

The efforts of several people made it possible to successfully complete the 1997 field season at Camp Bullis. The field team was a crew of very experienced, hard-working biologists who were able to step in and contribute from the outset. These included Fred Wills, Leslie Linehan, Mike Scully, Cricket Braun, and Dawn Garcia. Fred Wills took on the added responsibility of assisting with onsite, administrative coordination. Brian Pierce provided orienteering training and training in Golden-cheeked Warbler field work. Both he and Susan Rust were extremely supportive and shared their knowledge and experience with the author, which allowed him a familiarity with the strengths and weaknesses of the project that he would not have had otherwise. S. Rust also provided a Blackcapped Vireo training workshop. Marlin Sawyer worked continuously to oversee the project, lend administrative support, and obtain access to training areas. Dave Pierantoni and the Range Control office worked cooperatively to allow access to training areas.

Jackie Schlatter, Dusty Bruns, and other members of the Camp Bullis operations staff provided essential logistic support. Tim Hayden of USACERL conducted BCV field work, administered the contract, and was often called upon for his expertise. He, Robert Melton, and Leslie Jetté offered insight and comments on drafts of this report. Mary Huwa, Pam Northey, and Ernie Solano of the Center 
for Ecological Management of Military Lands administered financial and personnel concerns.

COL James A. Walter is the Commander of USACERL, and Dr. Michael J. O'Connor is Director. 


\section{Contents}

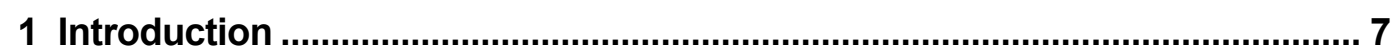

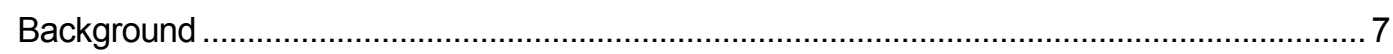

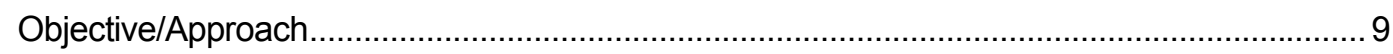

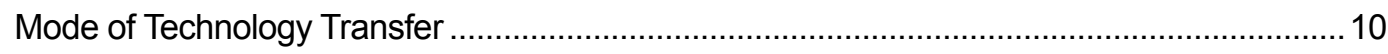

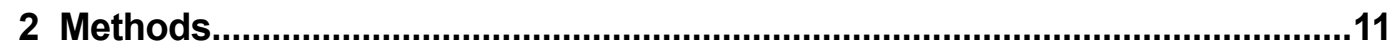

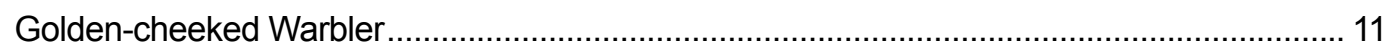

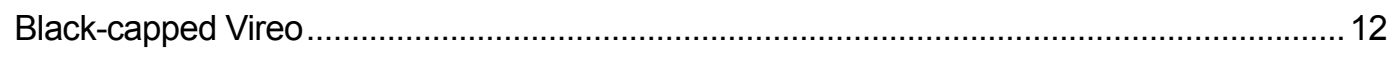

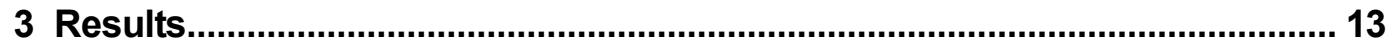

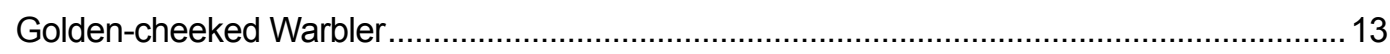

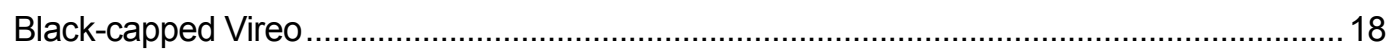

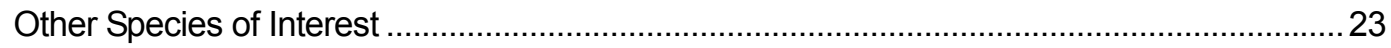

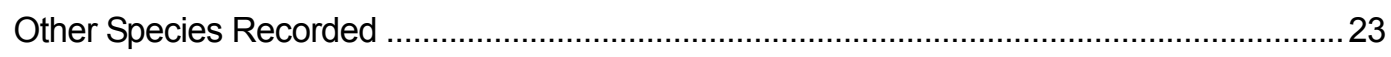

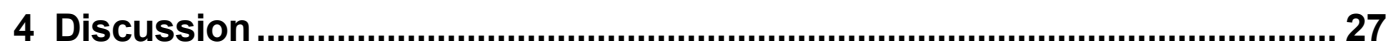

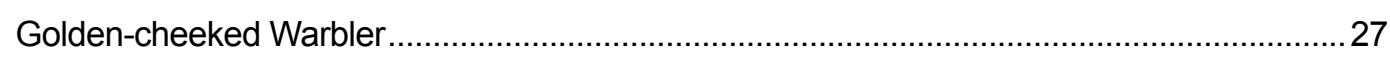

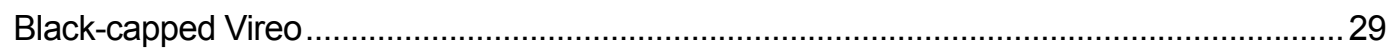

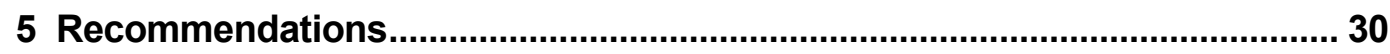

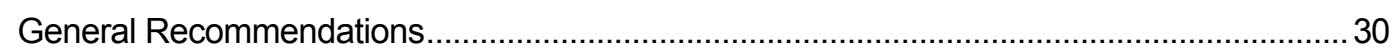

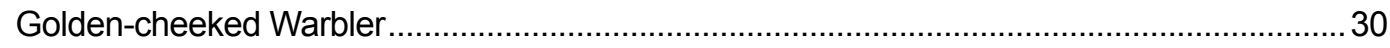

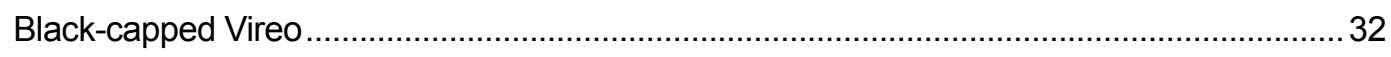

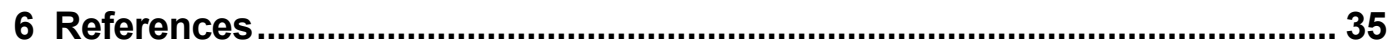

Distribution 


\section{List of Figures and Tables}

\section{Figures}

1 Map of Camp Bullis showing the three GCW subpopulations and areas of BCV activity in 1997.

2 BCV detections and possible detections in the live fire area on Camp Bullis in 1997.

3 BCV detections and possible detections outside of the live fire area on Camp Bullis in 1997.

\section{Tables}

1 Summary results of the GCW survey lines run on Camp Bullis in 1997

2 GCW detected at official observation points on subpopulation survey lines from 1991 to 1997.

3 Percent of survey lines where GCW have been detected at official observation points from 1991 to 1997

4 Estimated density of GCW subpopulations on Camp Bullis from 1991 to 1997.

5 List of BCV, and possible BCV, detections on Camp Bullis in 1997. ...................... 19

6 Historic occurrence of BCV on Camp Bullis............................................................ 24

7 Other species detected on GCW survey runs at Camp Bullis in 1997. ................... 25

8 List of nontarget species seen opportunistically on GCW and BCV surveys at Camp Bullis in 1997 


\section{Introduction}

\section{Background}

The Golden-cheeked Warbler (Dendroica chrysoparia) and Black-capped Vireo (Vireo atricapillus) are two endangered songbird species that nest on Camp Bullis, TX. Both are migratory and over-winter south of the United States border. The Golden-cheeked Warbler (GCW) was federally listed as an endangered species in 1990 (U.S. Fish and Wildlife Service [USFWS] 1990). Its entire breeding range lies within the borders of the state of Texas. Typical habitat consists of mature oak/juniper forest. Rapid and severe habitat loss was a key factor in determining its endangered status. GCW typically begin to arrive on Camp Bullis in mid-March (Stewardship Services 1993) and most nestlings appear to have fledged by early to mid-June. At the time of this writing (1997), the birds are thought to be primarily single brooded, but there is some evidence that second broods are reared. Nests are difficult to locate, as their outer layer is made with shredded bark from juniper trees, making them inconspicuous. Nest parasitism by the Brown-headed Cowbird (Molothrus ater) has been reported at GCW nests (Pulich 1976), but in at least one study from central Texas, there was little evidence of this (Jette, Hayden, and Cornelius Draft). Male GCWs appear to be site faithful, with return rates of approximately 50 percent reported, and up to 66 percent in one case (Jette, Hayden, and Cornelius Draft). The formal GCW monitoring regime as it is now conducted at Camp Bullis was initiated in 1991 (Rust and Watson 1995). That monitoring plan called for a survey consisting of 59 survey lines that covered approximately 9,026 hectares (ha) or $4 / 5$ of the installation (Stewardship Services 1993). Twenty-four of these lines were selected to census what is referred to as the three GCW subpopulations at Camp Bullis (Figure 1). These three subpopulations represent three areas of GCW concentration and include Bullis Hills (9 lines), Lewis Valley (8 lines), and Cibolo Creek (7 lines). Surveying in 1997 consisted of these 24 lines. 


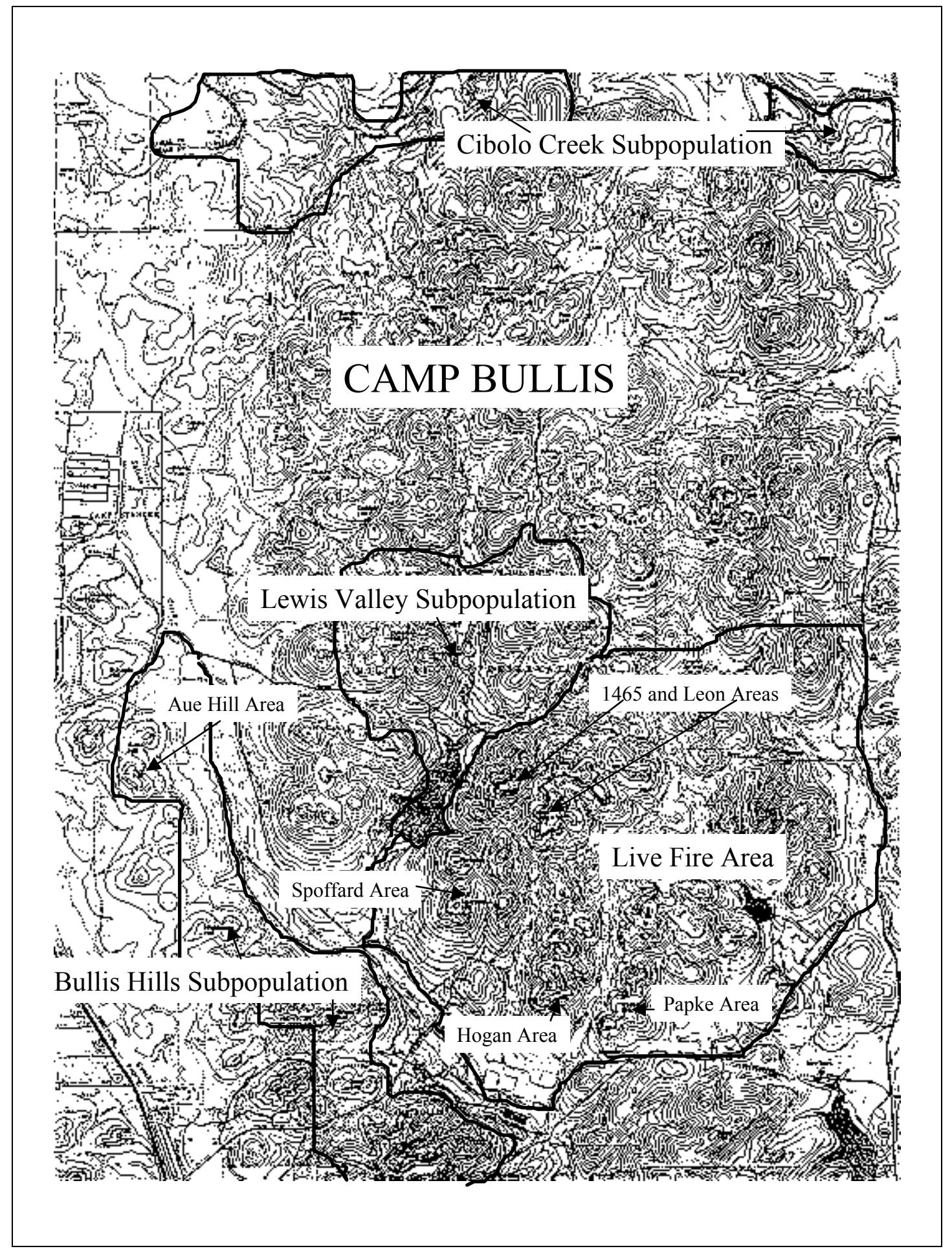

Figure 1. Map of Camp Bullis showing the three GCW subpopulations and areas of BCV activity in 1997.

The Black-capped Vireo (BCV) was federally listed as an endangered species in 1987 (USFWS 1987). Habitat loss, vulnerability to cowbird parasitism, and fire suppression are factors affecting the BCV population. The current breeding 
range of the BCV includes parts of Oklahoma, Texas, and Mexico. In central Texas, BCV typically begin to arrive on Camp Bullis in late March (Stewardship Services 1993). Nesting activities can last into August at some localities in central Texas. Tazik (1991) reported that 10 percent of all nest starts in 1989 on Fort Hood, TX, occurred in the period of July 2 to July 15. Such nests can be active into August if they do not fail before the fledging date. BCV usually nest in shrub habitat. Nests are typical of the genus Vireo, consisting of a small pendulous cup positioned in the fork of a small branch. Nests are often placed at heights of 0.5 to 2 meters. Studies in Texas and Oklahoma have reported that BCV can commonly rear two broods in a single season, and often renest after both failed and successful attempts if time permits. Biologists that have worked with BCV on Camp Bullis suspect birds there may be single-brooded and renest only after failed attempts (Stewardship Services, unpublished observations). BCV are extremely vulnerable to brood parasitism; parasitism rates of approximately 90 percent have been recorded on Fort Hood (Tazik 1991). Such intense levels of parasitism severely reduce nest success. Cowbird control programs in Texas and Oklahoma have proven to be very useful in mitigating the effects of parasitism. As with the GCW, male BCV appear to be quite site faithful. Tazik (1991) reported return rates of 64.7 percent in 1988 and 46.8 percent in 1989 for BCV on Fort Hood. Historically, fire has created and maintained habitat. Fire and mechanical disturbance are contemporary means by which land managers create and maintain habitat. A large portion of the known available habitat on Camp Bullis is found in the live fire area (Figure 1). BCV field work on Camp Bullis primarily involves field visits to known or potential habitat where abundance and distribution data are collected, as well as any opportunistic demographic data observed.

Camp Bullis is a subpost of Fort Sam Houston, TX, and is located just north of the city of San Antonio. The installation covers 11,283 ha of mostly rugged, hilly country on the southeastern edge of the Edwards Plateau. Camp Bullis is primarily used to provide training for U.S. Army medical, Air Force, and Army Reserve units. Tasked with monitoring these two endangered birds by directives in the Endangered Species Act, Camp Bullis has formally collected data on GCW since 1991 and on the BCV since 1989.

\section{Objective/Approach}

This report addresses the directives of the Endangered Species Act by describing the GCW and BCV monitoring program for the 1997 field season. It details the principle objective of the research, which is to use standard ornithological 
surveying techniques to estimate the distribution and abundance of these birds on Camp Bullis.

\section{Mode of Technology Transfer}

The results and recommendations in this report provide information that can assist biologists on Camp Bullis with land management decisions that will facilitate successful employment of the mission of the U.S. Army and compliance with the Endangered Species Act. 


\section{Methods}

The 1997 survey team consisted of experienced field biologists that represented a core of individuals who, for the most part, have been conducting field work on Camp Bullis for the past several years. All have been trained in bird monitoring and orienteering. Field biologists worked on both the GCW and BCV survey teams. Brief descriptions of GCW and BCV field protocol follow. Greater detail can be found in Stewardship Services, 1995a, b.

\section{Golden-cheeked Warbler}

GCW field surveys were conducted as they have been in the past, with biologists performing surveys along lines that have been strategically placed by Stewardship Services. Survey lines consist of line transects with a series of observation points. Lines have from 4 to 9 observation points at which the field observer records the number of GCW detected in a 10-minute time span. The points are separated by a distance of approximately $200 \mathrm{~m}$. Surveys began within an hour of sunrise and were finished before 11:30 in the morning. Inclement weather (rain, wind more than $15 \mathrm{mph}$, or temperatures below $45^{\circ} \mathrm{F}$ ) was cause to cancel a run in progress or to not initiate a run. Field workers also noted any Brown-headed Cowbird (BHC), White-eyed Vireo (WEV), and Blackthroated Green Warbler (BTG) that were detected. Special protocol was to be followed if a BCV was detected. Some field workers also kept a list of all bird species detected. Other information that was collected while on a survey run included vegetation descriptions at each observation point, and any events or comments of note. Details of the field protocol can be found in Stewardship Services (1995b). The window set by the USFWS for conducting the GCW field survey on Camp Bullis is March 20 to May 15.

The same method of estimating density that has been used for comparability in past years at Camp Bullis was also used in 1997. The estimate is based on a detection radius of $100 \mathrm{~m}$ at the observation points and is calculated as GCW per ha. GCW detections at lines that were run twice were averaged together to get a single estimate of GCW for those lines. Detections of GCW on survey lines and density estimates are two tools that can be used to estimate GCW trends. GCW presence/absence on survey lines can suggest where GCW are located; and density estimates can suggest GCW concentration. Both can be useful 
mechanisms used to help assess status and habitat use, but neither is infallible and both are coarse estimates. Data should be interpreted as guidelines rather than as absolute trends.

\section{Black-capped Vireo}

The primary goal of the survey effort for the BCV was to locate all BCV on the installation. BCV habitat is limited and dispersed throughout the installation, but most occurs in the live fire area. A number of sites that have been occupied in the past have been identified as the known principle nesting areas. There are other sites that appear to have usable habitat, but at which no occupation has been documented. All of these known areas were checked for BCVs. As time permitted, a secondary goal of the survey effort was to obtain as much information as possible about the territory. Information that addressed the mated status (presence of female), nesting status (e.g., a bird seen carrying nesting material), fecundity (number of fledglings documented), age (e.g., color and degree of black on nape and cap for males), and any other information (e.g., evidence of parasitism) was collected. Limited access has in the past precluded formal nest searching and monitoring activities. Some field workers kept a list of all of the bird species they detected. When there was access, field biologists spent only a reasonable amount of time at the site to obtain the desired data. If at any time the biologist suspected a bird was disturbed by their presence, they left the area. This is particularly true when birds are in sensitive stages of the nesting period, like nest building for example. Leaving a nest area is also critical when working in poor weather conditions; an incubating bird might flush from a nest at a time when incubation is necessary to protect the nest. Details of these protocols may be found in Stewardship Services (1995b). The allowed window set by the USFWS for BCV field work on Camp Bullis is April 10 to July 15. 


\section{Results}

\section{Golden-cheeked Warbler}

\section{GCW Field Notes}

The 1997 point count surveys at Camp Bullis began later in the season then they have typically begun in previous years. This delay resulted in a shortened period for field work. The time guidelines for GCW field work on Camp Bullis is March 20 to May 15. The first GCW survey in 1997 occurred on April 14. The field team was given a goal of completing two runs on as many of the 24 survey lines as possible. Eighteen of these lines were run twice, and six were run once in 1997. At the Bullis Hills subpopulation, two lines were run once and seven twice. At Cibolo Creek, three lines were run once and five twice. At Lewis Valley, one line was run once and six twice. The first survey run at the Bullis Hills subpopulation occurred on April 17. All first runs were completed by May 6 and any second runs were completed by May 25. (Note: It is not standard procedure to wait until all first runs are completed before second runs are attempted.) The first run at the Cibolo Creek subpopulation occurred on April 14. First runs were completed by May 11 and any second runs by May 27 . Lastly, the first survey at the Lewis Valley subpopulation occurred on April 14. First runs were completed by May 10 and any second runs by May 24. In total, first runs in 1997 were completed by May 11 and any second runs by May 27 . This compares to May 7 for first runs and May 17 for second runs for the same 24 subpopulation lines in 1996; May 2 for first runs and May 22 for second runs in 1995; April 12 for first runs and May 22 for second runs in 1994; April 15 for first runs and May 14 for second runs in 1993; April 14 for first runs (except for one line added during the season and completed on May 19) and May 23 for second runs in 1992; and April 21 for first runs and May 24 for second runs in 1991.

A field monitoring objective is to have first and second runs on the same line separated by a minimum period of 14 days. This occurred on 16 of the 18 lines in 1997. The two exceptions were at line 8B2 (Bullis Hills subpopulation), which had an interval of 12 days between runs, and at line 6A2 (Lewis Valley subpopulation), which had an interval of 11 days between runs. 
Another provision of survey protocol is that a line run for the second time should be run in the opposing direction of the first run. If the first run was north to south, the second run should be south to north. This was done at all 18 lines run twice.

Additionally, there were occasions when a survey run was cancelled because of inclement weather, or where data had been obtained in inclement weather and, therefore, that data was excluded from the analyses. Both the first, and portions of the third run of line 6A3 (Lewis Valley subpopulation) were not included in the analyses because of inclement weather. Also, four of six observation points at the first run of line 2A1 in the Cibolo Creek subpopulation were excluded from analyses because of inclement weather, but the line was successfully run twice later in the season.

\section{Results of the 1997 Survey Runs}

Overall, there were 64 acceptable cases of GCW documented on the 278 official observation points on all runs in the three subpopulations in 1997 . Table 1 summarizes the results of the GCW survey work. Additionally, there were 29 (plus one possible observation) cases at which a GCW was detected at locations outside of the official sampling points (outside = any observations along the transect occurring outside of the 10-minute observation period at an official sampling point). More GCW (33) were documented on survey lines in the Lewis Valley subpopulation than at either of the two other subpopulations (16 at Bullis Hills and 15 at Cibolo Creek). GCW were documented on 66.7 percent (16 of 24) of the subpopulation survey lines surveyed in 1997. A line at which a GCW was detected is often referred to as an "occupied" line. A line at which no GCW was detected is often referred to as an "unoccupied" line. Five of the nine survey lines at the Bullis Hills subpopulation were occupied. GCW were detected on 8 of the 16 (50 percent) individual runs at Bullis Hills. Line 8A1, surveyed once, had the highest total, with five GCW documented. In contrast, 6 of the 7 survey lines in the Lewis Valley subpopulation were occupied, and GCW were detected on 10 of 13 survey runs (76.9 percent). Five or more GCW were detected on four individual survey runs. The highest number of birds documented on a single run occurred on the first run of line $3 \mathrm{C} 2$, where eight GCW were detected. Five of eight of the survey lines at the Cibolo Creek subpopulation were occupied, and GCW were documented at 8 of the 13 (61.5 percent) survey runs. On one run (1B1) at Cibolo Creek four GCW were detected, but no other run had more than two. Overall, GCW were detected on 26 of the 42 (61.9 percent) runs, and 5 or more GCW were documented on 5 runs. 
Table 1. Summary results of the GCW survey lines run on Camp Bullis in 1997.

\begin{tabular}{|c|c|c|c|c|c|c|c|c|c|c|c|c|c|c|c|c|c|}
\hline \multirow[b]{2}{*}{ Line } & \multirow{2}{*}{$\begin{array}{l}\text { Sub- } \\
\text { population }\end{array}$} & \multirow[b]{2}{*}{ Run } & \multirow{2}{*}{$\begin{array}{l}\text { Direction } \\
\text { of } \\
\text { Run }\end{array}$} & \multirow[b]{2}{*}{ Date } & \multirow{2}{*}{$\begin{array}{l}\text { Total } \\
\text { \# of } \\
\text { Points }\end{array}$} & \multirow{2}{*}{$\begin{array}{l}\text { Point(s) } \\
\text { Excluded }\end{array}$} & \multicolumn{9}{|c|}{ GCW at Observation Point } & \multirow{2}{*}{$\begin{array}{l}\text { Total \# } \\
\text { of GCW } \\
\text { at Points }\end{array}$} & \multirow{2}{*}{$\begin{array}{l}\text { Other } \\
\text { GCW } \\
\text { Detections } \\
\end{array}$} \\
\hline & & & & & & & 1 & 2 & 3 & 4 & 5 & 6 & 7 & 8 & 9 & & \\
\hline 7.1 & Bullis & FIRST & W & 24-Apr & 7 & 0 & 0 & 0 & 0 & 0 & 0 & 0 & 0 & * & * & 0 & 0 \\
\hline 7.1 & Bullis & SECOND & $E$ & 21-Mav & 7 & 0 & 0 & 0 & 0 & 0 & 0 & 0 & 0 & * & * & 0 & 0 \\
\hline 7.2 & Bullis & FIRST & $\mathrm{N}$ & 29-Apr & 8 & 0 & 0 & 0 & 0 & 0 & 0 & 0 & 0 & 0 & * & 0 & 0 \\
\hline 7.2 & Bullis & SECOND & $S$ & 25-Mav & 8 & 0 & 0 & 0 & 1 & 0 & 0 & 0 & 0 & 0 & * & 1 & 0 \\
\hline 7.3 & Bullis & FIRST & WSW & 21-Apr & 5 & 0 & 0 & 0 & 0 & 0 & 0 & * & * & * & * & 0 & 0 \\
\hline 7.3 & Bullis & SECOND & ENE & 21-Mav & 5 & 0 & 0 & 0 & 0 & 0 & 0 & * & * & * & * & 0 & 0 \\
\hline 7.4 & Bullis & FIRST & $\mathrm{N}$ & 15-Apr & 6 & 0 & 0 & 0 & 0 & 0 & 0 & 0 & * & * & * & 0 & 0 \\
\hline $8 \mathrm{~A} 1$ & Bullis & FIRST & $S$ & 17-Apr & 7 & 0 & 0 & 0 & 2 & 0 & 0 & 1 & 0 & * & * & 3 & 2 \\
\hline $8 \mathrm{~A} 1$ & Bullis & SECOND & $\mathrm{N}$ & 13-Mav & 7 & 0 & 0 & 0 & 0 & 0 & 0 & 0 & 1 & * & * & 1 & 0 \\
\hline $8 \mathrm{~A} 2$ & Bullis & FIRST & WNW & 7-Mav & 6 & 0 & 0 & 1 & 0 & 0 & 3 & 1 & * & * & * & 5 & 0 \\
\hline 8B1 & Bullis & FIRST & S & 17-Apr & 5 & 0 & 0 & 0 & 0 & 0 & 1 & * & * & * & * & 1 & 0 \\
\hline 8B1 & Bullis & SECOND & $\mathrm{N}$ & 10-Mav & 5 & 0 & 0 & 2 & 0 & 0 & 0 & * & * & * & * & 2 & 0 \\
\hline $8 \mathrm{~B} 2$ & Bullis & FIRST & W & 6-Mav & 8 & 0 & 0 & 0 & 2 & 0 & 0 & 0 & 0 & 0 & * & 2 & 1 \\
\hline $8 \mathrm{~B} 2$ & Bullis & SECOND & ENE & 18-Mav & 8 & 0 & 0 & 0 & 0 & 0 & 0 & 0 & 1 & 0 & * & 1 & 0 \\
\hline $8 \mathrm{~B} 3$ & Bullis & FIRST & W & 19-Apr & 8 & 0 & 0 & 0 & 0 & 0 & 0 & 0 & 0 & 0 & * & 0 & 0 \\
\hline $8 \mathrm{~B} 3$ & Bullis & SECOND & $E$ & 18-May & 8 & 0 & 0 & 0 & 0 & 0 & 0 & 0 & 0 & 0 & * & 0 & 1 \\
\hline $1 \mathrm{~A} 1$ & Cibolo & FIRST & $\mathrm{NE}$ & 16-Apr & 6 & 0 & 0 & 0 & 0 & 0 & 0 & 1 & * & * & * & 1 & 0 \\
\hline $1 \mathrm{~A} 1$ & Cibolo & SECOND & SW & 16-Mav & 6 & 0 & 0 & 0 & 0 & 0 & 0 & 1 & * & * & * & 1 & 3 \\
\hline $1 \mathrm{~A} 2$ & Cibolo & FIRST & W & 8-Mav & 6 & 0 & 0 & 1 & 0 & 1 & 0 & 0 & * & * & * & 2 & 1 \\
\hline 1B1 & Cibolo & FIRST & ESE & 6-Mav & 8 & 0 & 1 & 0 & 1 & 1 & 0 & 0 & 0 & 1 & * & 4 & 1 \\
\hline 1B2 & Cibolo & FIRST & $E$ & 6-May & 7 & 0 & 0 & 0 & 0 & 0 & 0 & 0 & 0 & * & * & 0 & 1 \\
\hline $2 \mathrm{~A} 1$ & Cibolo & FIRST & SW & 11-May & 6 & 0 & 1 & 0 & 0 & 0 & 0 & 1 & * & * & * & 2 & 1 \\
\hline $2 \mathrm{~A} 1$ & Cibolo & SECOND & $\mathrm{NE}$ & 25-May & 6 & 0 & 2 & 0 & 0 & 0 & 0 & 0 & * & * & * & 2 & 0 \\
\hline $2 \mathrm{~A} 2$ & Cibolo & FIRST & $\mathrm{N}$ & 11-Mav & 6 & 0 & 0 & 0 & 0 & 0 & 0 & 2 & * & * & * & 2 & 0 \\
\hline $2 \mathrm{~A} 2$ & Cibolo & SECOND & S & 27-Mav & 6 & 0 & 1 & 0 & 0 & 0 & 0 & 0 & * & * & * & 1 & 0 \\
\hline 2D1 & Cibolo & FIRST & $N$ & 14-Apr & 4 & 0 & 0 & 0 & 0 & 0 & * & * & * & * & * & 0 & 0 \\
\hline 2D1 & Cibolo & SECOND & $S$ & 14-Mav & 4 & 0 & 0 & 0 & 0 & 0 & * & * & * & * & * & 0 & 0 \\
\hline 2D2 & Cibolo & FIRST & NNW & 1-May & 6 & 0 & 0 & 0 & 0 & 0 & 0 & 0 & * & * & * & 0 & 0 \\
\hline $2 \mathrm{D} 2$ & Cibolo & SECOND & SSE & 17-Mav & 6 & 0 & 0 & 0 & 0 & 0 & 0 & 0 & * & * & * & 0 & 1? \\
\hline $3 \mathrm{C} 1$ & Lewis & FIRST & SE & 18-Apr & 7 & 0 & 0 & 0 & 0 & 0 & 0 & 1 & 0 & * & * & 1 & 0 \\
\hline $3 \mathrm{C} 2$ & Lewis & FIRST & ENE & 30-Apr & 8 & 0 & 0 & 0 & 1 & 3 & 2 & 1 & 0 & 1 & * & 8 & 3 \\
\hline $3 \mathrm{C} 2$ & Lewis & SECOND & SW & 17-Mav & 8 & 0 & 0 & 0 & 0 & 1 & 1 & 1 & 0 & 0 & * & 3 & 0 \\
\hline $4 \mathrm{C} 1$ & Lewis & FIRST & SE & 20-Apr & 8 & 0 & 0 & 0 & 0 & 0 & 0 & 0 & 1 & 1 & * & 2 & 7 \\
\hline $4 \mathrm{C} 1$ & Lewis & SECOND & NW & 13-Mav & 8 & 0 & 1 & 1 & 0 & 2 & 0 & 0 & 0 & 1 & * & 5 & 2 \\
\hline $4 \mathrm{C} 2$ & Lewis & FIRST & ENE & 14-Apr & 7 & 0 & 0 & 2 & 0 & 0 & 0 & 0 & 0 & * & * & 2 & 0 \\
\hline $4 \mathrm{C} 2$ & Lewis & SECOND & SW & 18-May & 7 & 0 & 0 & 0 & 0 & 0 & 0 & 1 & 0 & * & * & 1 & 0 \\
\hline $4 \mathrm{C} 3$ & Lewis & FIRST & SE & 10-Mav & 6 & 5 & 0 & 0 & 0 & 0 & * & 0 & * & * & * & 0 & 0 \\
\hline $4 \mathrm{C3}$ & Lewis & SECOND & NW & 24-Mav & 6 & 0 & 0 & 0 & 0 & 0 & 0 & 0 & * & * & * & 0 & 0 \\
\hline $6 \mathrm{~A} 2$ & Lewis & FIRST & SE & 4-Mav & 7 & 0 & 0 & 0 & 0 & 0 & 0 & 0 & 0 & * & * & 0 & 2 \\
\hline $6 \mathrm{~A} 2$ & Lewis & SECOND & WNW & 15-Mav & 7 & 0 & 1 & 0 & 0 & 0 & 0 & 0 & 0 & * & * & 1 & 0 \\
\hline $6 \mathrm{~A} 3$ & Lewis & FIRST & NNE & 4-Mav & 9 & 0 & 0 & 0 & 0 & 0 & 3 & 0 & 1 & 1 & 0 & 5 & 2 \\
\hline $6 \mathrm{~A} 3$ & Lewis & SECOND & SSW & 22-Mav & 9 & $7,8,9$ & 1 & 2 & 2 & 0 & 0 & 0 & * & * & * & 5 & 2 \\
\hline Total & & & & & & & & & & & & & & & & 64 & $29(+1 ?)$ \\
\hline
\end{tabular}




\section{Comparisons of Subpopulations: 1991 through 1997}

More lines at the Lewis Valley subpopulation have been occupied in at least 6 of the 7 years than lines at the other subpopulations (Tables 2 and 3). In the 7 years of monitoring, 3 of the 7 (42.9 percent) survey lines at the Lewis Valley subpopulation were occupied in all 7 years, and 5 (71.4 percent) were occupied in at least 6 of the 7 years. Unlike most of the lines at Lewis Valley, there was a GCW documented in only 1 year at line 6A2. Line 4C3 had a GCW documented in 3 years. Otherwise, the lines at Lewis Valley were occupied in 6 or more years. In contrast, 1 of 9 survey lines (11.1 percent) at the Bullis Hills subpopulation was occupied in each year, and 3 (33.3 percent) were occupied in at least 6 years. Four lines (44.4 percent) at the Bullis Hills subpopulation were occupied in 4 or fewer of the 7 years. Two of the 8 lines (25.0 percent) at the Cibolo Creek subpopulation have had birds detected in each year, and 4 (50.0 percent) were occupied in at least 6 years.

\section{Installation-wide Comparison of Survey Lines: 1991 through 1997}

From 1991 to 1997, the percent of survey lines that were occupied on the installation, annually, ranged from a low of 56.5 percent (1993) to a high of 87.5 percent (1995, Table 2). The 7-year average of the annual percentages of lines that were occupied is 72.7 percent. The percent of occupied survey lines has been constant the past 2 years (1996 and 1997), with birds recorded on 66.7 percent of the lines in each year. The number of unoccupied lines at each subpopulation was also constant (although occupation at specific points, or specific lines varied) the past two seasons. There were three unoccupied lines at Cibolo Creek in 1996 and 1997; two in 1996 and one in 1997 at Lewis Valley; and three in 1996 and four in 1997 at Bullis Hills.

\section{GCW Density Estimates}

Density estimates suggest that the Lewis Valley subpopulation had the greatest concentration of GCW with 0.108 per ha (Table 4). Comparable estimates at the Bullis Hills subpopulation were 0.056 GCW per ha and 0.068 at the Cibolo Creek subpopulation. The overall estimate of density was $0.076 \mathrm{GCW}$ per ha in 1997. 
Table 2. GCW detected at official observation points on subpopulation survey lines from 1991 to 1997.

\begin{tabular}{|c|c|c|c|c|c|c|c|c|c|}
\hline LINE & SUBPOPUATION & 1991 & 1992 & 1993 & 1994 & 1995 & 1996 & 1997 & TOTAL \\
\hline $1 \mathrm{~A} 1$ & Cibolo & YES* & YES & YES & YES & YES & YES & YES & 7 OF 7 \\
\hline $1 \mathrm{~A} 2$ & Cibolo & YES & YES & YES & NO & YES & YES & YES & 6 OF 7 \\
\hline 1B1 & Cibolo & YES & YES & YES & YES & YES & YES & YES & 7 OF 7 \\
\hline 1B2 & Cibolo & YES & NO & YES & YES & YES & YES & NO & 5 OF 7 \\
\hline $2 \mathrm{~A} 1$ & Cibolo & YES & YES & YES & YES & YES & NO & YES & 6 OF 7 \\
\hline $2 \mathrm{~A} 2$ & Cibolo & YES & NO & YES & YES & NO & NO & YES & 4 OF 7 \\
\hline 2D1 & Cibolo & YES & YES & $* *$ & $* *$ & YES & NO & NO & 3 OF 5 \\
\hline 2D2 & Cibolo & $* *$ & YES & NO & NO & NO & YES & NO & 2 OF 6 \\
\hline $3 \mathrm{C} 1$ & Lewis & YES & YES & NO & YES & YES & YES & YES & 6 OF 7 \\
\hline $3 \mathrm{C} 2$ & Lewis & YES & YES & NO & YES & YES & YES & YES & 6 OF 7 \\
\hline $4 \mathrm{C} 1$ & Lewis & YES & YES & YES & YES & YES & YES & YES & 7 OF 7 \\
\hline $4 \mathrm{C} 2$ & Lewis & YES & YES & YES & YES & YES & YES & YES & 7 OF 7 \\
\hline $4 \mathrm{C} 3$ & Lewis & YES & NO & NO & YES & YES & NO & NO & 3 OF 7 \\
\hline $6 \mathrm{~A} 2$ & Lewis & NO & NO & NO & NO & NO & NO & YES & 1 OF 7 \\
\hline $6 \mathrm{~A} 3$ & Lewis & YES & YES & YES & YES & YES & YES & YES & 7 OF 7 \\
\hline 7.1 & Bullis & YES & YES & NO & YES & YES & NO & NO & 4 OF 7 \\
\hline 7.2 & Bullis & YES & NO & NO & YES & YES & NO & YES & 4 OF 7 \\
\hline 7.3 & Bullis & NO & NO & NO & YES & YES & NO & NO & 2 OF 7 \\
\hline 7.4 & Bullis & NO & YES & NO & YES & YES & YES & NO & 4 OF 7 \\
\hline $8 \mathrm{~A} 1$ & Bullis & NO & YES & YES & YES & YES & YES & YES & 6 OF 7 \\
\hline $8 \mathrm{~A} 2$ & Bullis & YES & YES & YES & YES & YES & YES & YES & 7 OF 7 \\
\hline 8B1 & Bullis & NO & YES & YES & NO & YES & YES & YES & 5 OF 7 \\
\hline 8B2 & Bullis & YES & NO & NO & YES & YES & YES & YES & 5 OF 7 \\
\hline 8B3 & Bullis & YES & YES & YES & YES & YES & YES & NO & 6 OF 7 \\
\hline \multirow[t]{2}{*}{ TOTAL } & & 18 OF 23 & 17 OF 24 & 13 OF 23 & 19 OF 23 & 21 OF 24 & 16 OF 24 & 16 OF 24 & \\
\hline & & $78.3 \%$ & $70.8 \%$ & $56.5 \%$ & $82.6 \%$ & $87.5 \%$ & $66.7 \%$ & $66.7 \%$ & \\
\hline
\end{tabular}

${ }^{*}$ YES $=$ occupied line, NO = unoccupied line.

** $=$ No data

Historic data generated by S. Rust (for years prior to and including 1995) and D. Thurber (1996).

\section{Comparison of GCW Density Estimates at Local Subpopulations: 1991 through 1997}

The estimated density of GCW per survey point has generally been higher at the Lewis Valley subpopulation than at the other subpopulations. Density estimates for the Lewis Valley subpopulation have ranged from 0.052 GCW per point to 0.125 (Table 4). It was equal to or greater than 0.080 in 5 of the past 7 years, with 1993 and 1994 being the exceptions. In contrast, the estimate of density has never been greater than 0.078 at Cibolo Creek (range $=0.049$ to 0.078 ) or 0.085 at Bullis Hills (range $=0.021$ to 0.085). 
Table 3. Percent of survey lines where GCW have been detected at official observation points from 1991 to 1997.

\begin{tabular}{llll}
\hline \multirow{2}{*}{\begin{tabular}{l} 
Occupied \\
\cline { 2 - 4 } Cibolo Creek
\end{tabular}} & Lewis Valley & Bullis Hills \\
\hline 7 & $25.0 \%$ & $42.9 \%$ & $11.1 \%$ \\
6 & $25.0 \%$ & $28.6 \%$ & $22.2 \%$ \\
5 & $12.5 \%$ & 0 & $22.2 \%$ \\
4 & $12.5 \%$ & 0 & $33.3 \%$ \\
3 & $12.5 \%^{*}$ & $14.3 \%$ & 0 \\
2 & $12.5 \%^{* *}$ & 0 & $11.1 \%$ \\
1 & 0 & $14.3 \%$ & 0 \\
0 & 0 & 0 & 0 \\
\hline
\end{tabular}

* Line surveyed in 5 years.

${ }^{* *}$ Line surveyed in 6 years.

Table 4. Estimated density of GCW subpopulations on Camp Bullis from 1991 to 1997.

\begin{tabular}{lllll} 
Year* & Cibolo Creek & Lewis Valley & Bullis Hills & Subpopulation Total \\
\hline 1991 & .071 & .113 & .053 & .078 \\
1992 & .075 & .125 & .058 & .085 \\
1993 & .078 & .052 & .021 & .048 \\
1994 & .049 & .073 & .058 & .060 \\
1995 & .065 & .080 & .085 & .077 \\
1996 & .073 & .101 & .056 & .076 \\
1997 & .068 & .108 & .056 & .076 \\
7 Year Average & .068 & .093 & 0.55 & .071 \\
\hline
\end{tabular}

Historic data for years prior to 1997 were generated by S. Rust (up to and including 1995) and D. Thurber (1996).

\section{Comparison of Installation-wide GCW Density Estimates: 1991 through 1997}

Overall, there were 0.076 GCW detected per ha in 1997 (Table 4). This compares favorably to the annual, installation-wide estimates of past years. Density estimates for each year in 1991 through 1997 have ranged from a low of 0.048 per ha in 1993 to a high of 0.085 in 1992. Estimates have been consistent the past 3 years with estimates of 0.077 in 1995, 0.076 in 1996, and 0.076 in 1997.

\section{Black-capped Vireo}

\section{BCV Field Notes}

The 1997 BCV field season was characterized by greater access to the live fire area than in 1996. Access to the live fire area in 1996 was granted on only five occasions; two of those occurred on April 2 and April 7. Both of these dates are early in the vireo breeding season and the BCV might not have settled onto 
territories by this time. The remaining three dates of field work in the live fire area were April 26, May 6, and May 24. There were no access days in June or July in the live fire area in 1996. In contrast, despite the later start in 1997, there were a total of 22 days when BCV field work was conducted and 13 of these days when work was conducted in the live fire area. Three field days were used in April (and one in the live fire area), seven in May (six in the live fire area), eight in June (four in the live fire area), and four in July (two in the live fire area). Although greater access was achieved in 1997, available days were, at times, clumped together. Availability that is more evenly dispersed throughout the breeding season is an objective to pursue.

\section{BCV Occupation in 1997}

Researchers visited all previously identified areas that were either occupied or potential BCV areas. A total of 12 male BCV were documented (Table 5). Locations of the general region of occupation are depicted in Figure 1. Figures 2 and 3 show these areas on a finer scale. Nearly all observations of BCV occurred in the live fire area. Only one, a BCV on Aue Hill, was documented outside of the live fire area (Table 5, Figure 3). Inside the live fire area there were two cases of BCV on Hogan 1, three on Hogan 2, two on Hogan 3, one on Hill 1465, another on Leon Hill, and two on Spoffard Hill. Additionally, there was evidence for five additional BCVs. The three birds with more conclusive evidence included a possible bird on the northwest side of Hogan 1, another on Papke Cap, and another on the west-southwest slope of Hogan 3. In each of these three cases, the field observer involved strongly suspected BCV presence based on vocals heard, but vocals or visuals were not verified. One of the two birds with unsubstantiated evidence occurred on a hill just southeast of Aue Hill and the other on Spoffard Hill.

There were five official, and at least two unofficial searches on Sykes Hill, a hill outside of the live fire area. This area housed BCV in 1996, but not in 1997. Other areas outside the live fire area that were searched include training area $11 \mathrm{~A}$, Ransom Hill in training area $3 \mathrm{~A}$, training area $8 \mathrm{~A}$, and several hills in training area 7 .

Table 5. List of BCV, and possible BCV, detections on Camp Bullis in 1997.

\begin{tabular}{lll}
\hline & 12 Confirmed BCV & Comments \\
\hline 1 & Hogan 1 SE & Pair present \\
2 & Hogan 1 S & Male seen/heard on multiple visits \\
3 & Hogan 2 S & Male, female, 2 fledglings
\end{tabular}




\begin{tabular}{|c|c|c|}
\hline 4 & Hogan 2 W & Male seen/heard on multiple visits \\
\hline 5 & Hogan 2 NE & Male seen/heard on multiple visits \\
\hline 6 & Hogan 3 SE & Male seen/heard on multiple visits \\
\hline 7 & Hogan $3 \mathrm{~S}$ & Male, female, 3 fledglings \\
\hline 8 & Leon SW \& SE & $\begin{array}{l}\text { Apparent first year male seen/heard on multiple visits covering } \\
\text { area in both tradional territory sites }\end{array}$ \\
\hline 9 & 1465 S \& E & $\begin{array}{l}\text { Male seen/heard on multiple visits covering area in both traditional } \\
\text { territory sites }\end{array}$ \\
\hline 10 & Aue S & Male vocalizes and is very mobile. Documented on single visit \\
\hline 11 & Spoffard SE & Male seen/heard on multiple visits \\
\hline \multirow[t]{2}{*}{12} & Spoffard SW & Pair present \\
\hline & 5 Possible BCV & \\
\hline 13 & Hogan $3 \mathrm{~W}$ & $\begin{array}{l}\text { Song \& vocals heard. Not known if it was one of known birds on } \\
\text { Hogan } 3\end{array}$ \\
\hline 14 & Hogan $1 \mathrm{~W}$ & $\begin{array}{l}\text { Male discovered when known male to south no longer detected, } \\
\text { and slighlty N of traditional " } 1 \mathrm{~W} \text { " site }\end{array}$ \\
\hline 15 & Papke Cap & Brief episodes of song. Observer $90 \%$ sure it was BCV \\
\hline 16 & Spoffard SI & $\begin{array}{l}\text { Observers thought a 3rd male was interacting with } 2 \text { known males, } \\
\text { but not sure. }\end{array}$ \\
\hline 17 & Aue Hill SE & Faint song heard from distance. Not detected on follow-up visit \\
\hline
\end{tabular}

\section{Historic BCV Occupation: 1989 through 1997}

A review of historic occupation (Table 6) indicates that BCV detected in 1997 were located primarily in areas where BCV have previously been documented. Three sites, Hogan 1SE, Hogan 2S, and $1465 \mathrm{~S}$ have been occupied every year since 1989. A majority of the historic sites have been occupied between 3 and 5 years. Some historic sites (e.g., Hogan 1S, Hogan 1W, Papke S, and most Sykes sites) were primarily occupied before 1994. There were a few sites newly recognized in 1997 (e.g., Spoffard sites, Hogan 2NE).

The minimum number of BCV in the TOTAL row of each year (or only number in the case of 1989 and 1993) in Table 6 represents the number of confirmed BCV for that year. Between 1989 and 1997, there was an average minimum number of BCV detected of 10.55. Access has varied in some years, so this likely does not 


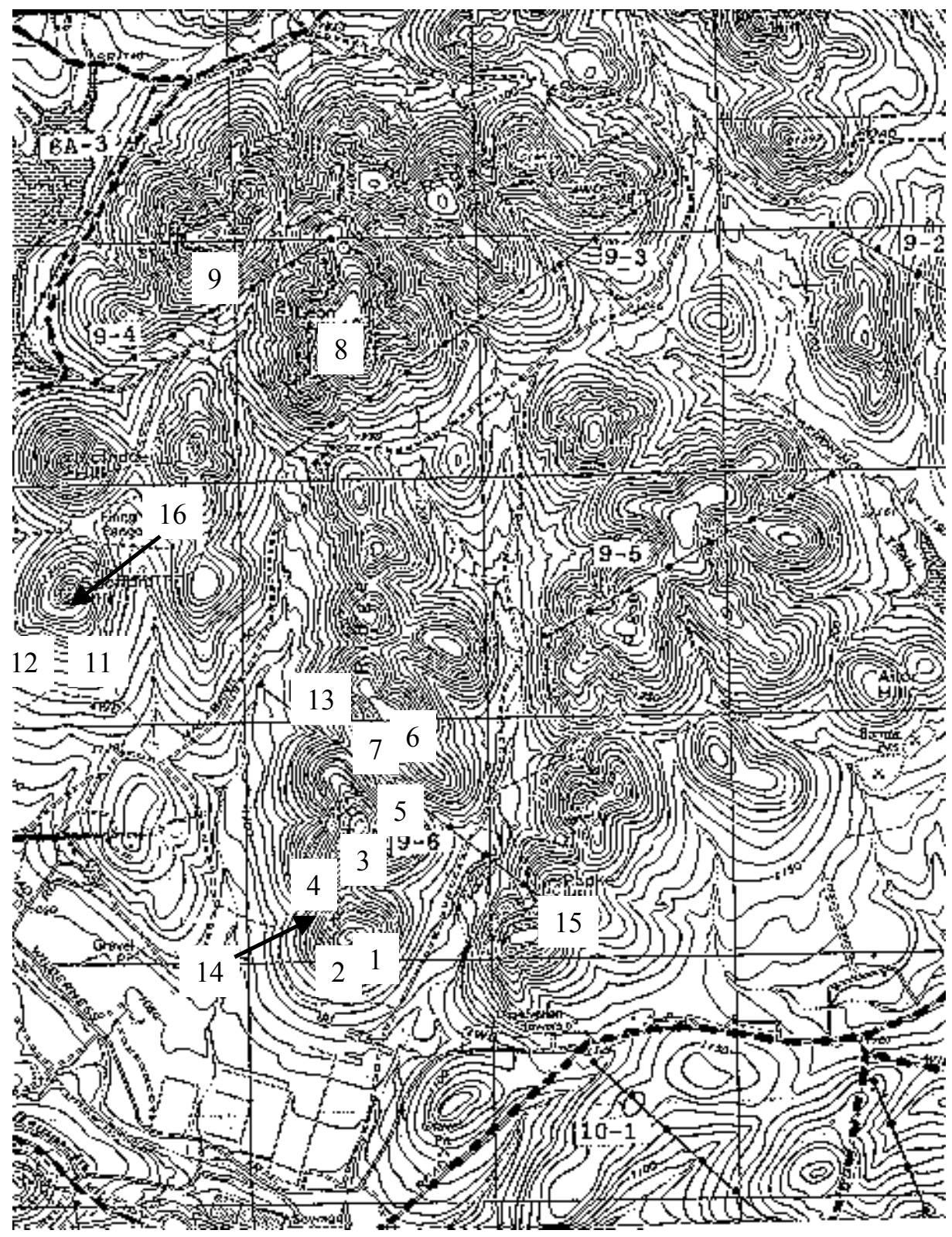

Figure 2. BCV detections and possible detections in the live fire area on Camp Bullis in $1997 .{ }^{1}$

\footnotetext{
${ }^{1}$ Numbers correspond to identify numbers in Tables 5 and 6 . Numbered sites represent general areas of occupation and not specifically defined territories.
} 


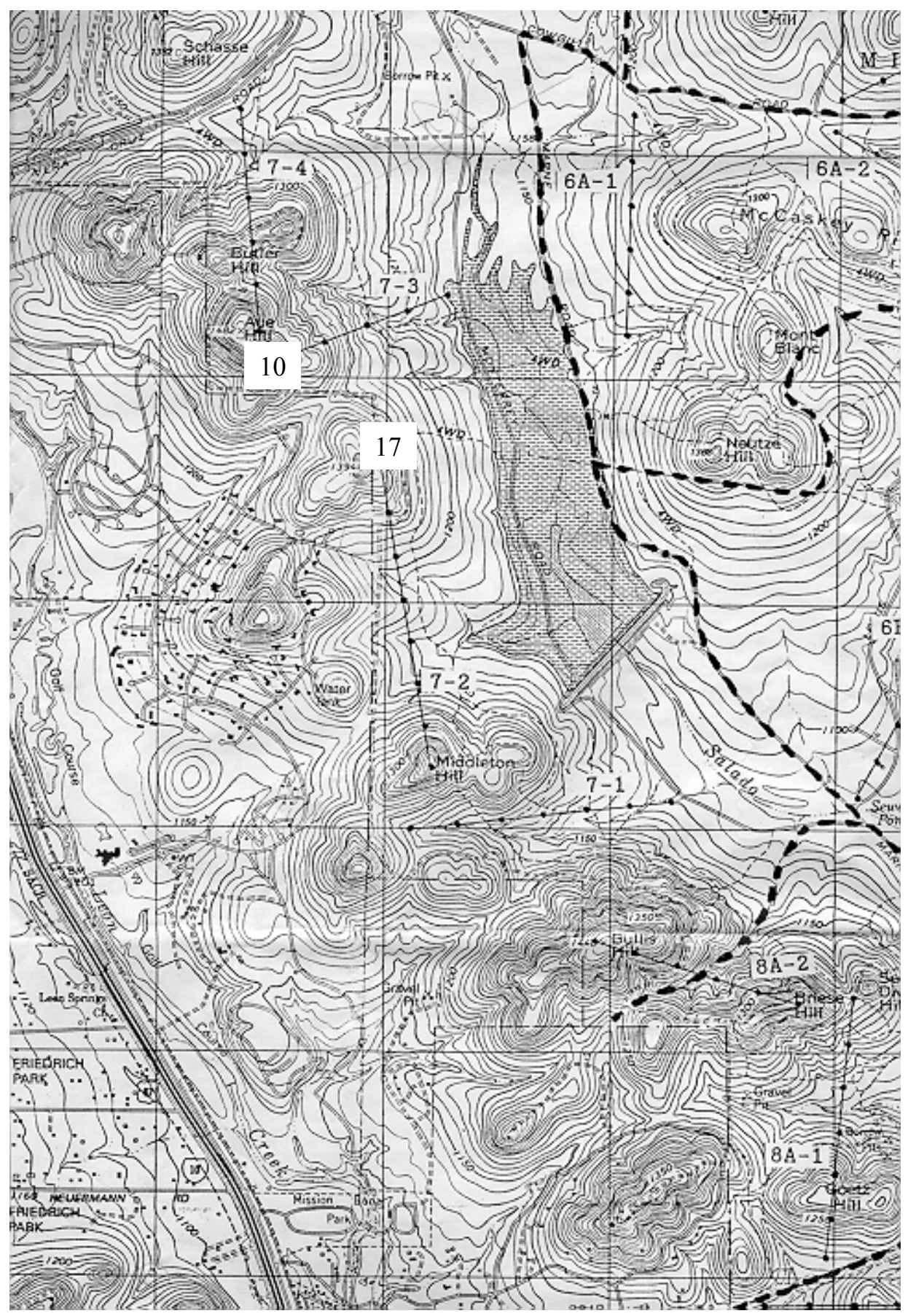

Figure 3. BCV detections and possible detections outside of the live fire area on Camp Bullis in $1997 .^{2}$

\footnotetext{
${ }^{2}$ Numbers correspond to identifying numbers in Tables 5 and 6 . Numbered sites represent general areas of occupation and not specifically defined territories.
} 
represent all the BCV actually present in a given year, but it offers a rudimentary index. Both 1995 and 1996 fell below this average.

\section{Anecdotal Demographic BCV Information}

As the primary goal of the BCV monitoring effort in 1997 was to locate BCVs, any information pertaining to the mated status or productivity related to BCV was the result of opportunistic observations. Four of the 12 cases where BCV were documented had evidence of females and in two cases fledglings were discovered (Table 5). In one case (Hogan 3S) three fledglings were discovered and at the other, (Hogan 2S), two fledglings were discovered. No BCV were seen tending to cowbird fledglings.

\section{Other Species of Interest}

A total of 100 observations at official observation points on GCW survey lines cited either the Brown-headed Cowbird, White-eyed Vireo, or Black-throated Green Warbler (Table 7). There were 31 additional recordings of these species occurring at times and places other than at the official observation times and points. Overall, there were 68 observations of $\mathrm{BHC}$ at observation points and 25 additional sightings, 31 observations of WEV at observation points and 3 additional sightings, and 1 observation of BTG at an observation point and 3 other sightings.

\section{Other Species Recorded}

Some field biologists listed all birds recorded while in the field. The final list is shown in Table 8. In total, 77 different species were recorded, plus 1 unknown finch species. This does not represent a thorough census, but is an accumulation. The list includes eight warbler, six flycatcher, five sparrow, four swallow, three vireo, three dove, four hawk, and three finch species, in addition to several other groups represented by one or two species. A number of the species detected were seen during the spring migration period and do not nest on Camp Bullis. 
Table 6. Historic occurrence of BCV on Camp Bullis.

\begin{tabular}{|c|c|c|c|c|c|c|c|c|c|}
\hline Territory & 1989 & 1990 & 1991 & 1992 & 1993 & 1994 & 1995 & 1996 & 1997 \\
\hline Hogan 1NE & & $x$ & & & & & & & \\
\hline Hogan 1SE & $x$ & $x$ & $X$ & $x$ & $x$ & $x$ & $x$ & $x$ & $X(1)$ \\
\hline Hogan 1S & $x$ & $x$ & $x$ & $x$ & & & & & $X(2)$ \\
\hline Hogan 1W & $x$ & & $x$ & $x$ & & & & & $\begin{array}{l}X ?(14 \text {, slightly } N \\
\text { of tradional } 3 \mathrm{~W} \\
\text { site) }\end{array}$ \\
\hline Hogan 2S & $x$ & $x$ & $x$ & $x$ & $X$ & $X$ & $X$ & $x$ & $X(3)$ \\
\hline Hogan 2W & $x$ & $x$ & $x$ & & $x$ & $x$ & $X ?$ & & $X(4)$ \\
\hline $\begin{array}{l}\text { Hogan } 2 \\
\mathrm{NE}\end{array}$ & & & & & & & & & $X(5)$ \\
\hline Hogan 3SE & $x$ & $x$ & $x$ & $x$ & $x$ & $x$ & $x$ & $x$ & $X(6)$ \\
\hline Hogan 3W & & & & & & & & & $X ?(13)$ \\
\hline Hogan $3 S$ & & & & & & & & & $\mathrm{X}(7)$ \\
\hline Hogan 4S & & $x$ & & & & $x$ & & & \\
\hline Papke Cap & & & & & & & & & $X ?(15)$ \\
\hline Papke S & $x$ & $x$ & & & & & & & \\
\hline Papke W & & $x ?$ & & & & & & & \\
\hline Leon $\mathrm{N}$ & $x$ & $x ?$ & & & & & & & \\
\hline Leon SW & $x$ & $x$ & $X$ & $X$ & $X$ & $X$ & $X ?$ & & $X(8$, on border of \\
\hline Leon SE & & $X ?$ & $x$ & $x$ & $x$ & & & $x ?$ & Leon SW \& SE) \\
\hline Otis SW & $x$ & & & & $x$ & $\mathrm{x}$ & $x$ & & \\
\hline Otis SE & $x$ & & & & $x$ & $x$ & $x$ & $x ?$ & \\
\hline $1465 \mathrm{~S}$ & $x$ & $x$ & $x$ & $x$ & $x$ & $x$ & $x$ & $x$ & $X(9$, on border of \\
\hline $1465 E$ & $x$ & $x$ & $x ?$ & & $x$ & $x$ & & $x$ & $1465 S \& E)$ \\
\hline Aue S & $x$ & $x$ & & $x ?$ & $x$ & & $x$ & & $X(10)$ \\
\hline Aue Cap & $x$ & & & & & & & & \\
\hline $\begin{array}{l}\text { Aue Hills } \\
\text { SE }\end{array}$ & & & & & & & & & $X ?(17)$ \\
\hline Sykes Cap & & $x$ & & & & & & $\mathrm{x}$ & \\
\hline Sykes W & & & $x$ & $x$ & $x$ & & & & \\
\hline Sykes S & & & $x$ & & & $X ?$ & & & \\
\hline Ransom & & & $x ?$ & $X ?$ & & & & & \\
\hline $\begin{array}{l}\text { Spoffard } \\
\text { SE }\end{array}$ & & & & & & & & & $X(11)$ \\
\hline $\begin{array}{l}\text { Spoffard } \\
\text { SW }\end{array}$ & & & & & & & & & $X(12)$ \\
\hline Spoffard S & & & & & & & & & $X ?(16)$ \\
\hline TOTAL & 15 & 13-16 & $11-13$ & $9-11$ & 12 & $10-11$ & $7-9$ & $6-8$ & $12-17$ \\
\hline
\end{tabular}

A "?" denotes a bird not 100 percent verified. Numbers in paranthesis for 1997 entries correspond to the BCV identifying numbers in Figures 2 and 3 and in Table 5.

Data for 1989 was collected by D. Tazik. S. Rust compiled this table for years prior to and including 1995. D. Thurber included data from 1996. 
Table 7. Other species detected on GCW survey runs at Camp Bullis in 1997.

\begin{tabular}{|c|c|c|c|c|c|c|c|c|c|c|c|}
\hline \multicolumn{4}{|c|}{ Bullis Hills } & \multicolumn{4}{|c|}{ Cibolo Creek } & \multicolumn{4}{|c|}{ Lewis Valley } \\
\hline Line & $\mathrm{BHC}^{* *}$ & WEV & BTG & Line & $\mathrm{BHC}$ & WEV & BTG & Line & $\mathrm{BHC}$ & WEV & BTG \\
\hline 7.1 & 1 & 1 & 0 & $1 \mathrm{~A} 1$ & $7,{ }^{*} 3$ & $6,{ }^{*} 1$ & 0 & $3 \mathrm{C} 1$ & 0 & 0 & 0 \\
\hline 7.2 & $7,{ }^{*} 10$ & 0 & 0 & $1 \mathrm{~A} 2$ & 9 & 2 & $0,{ }^{*} 1$ & $3 \mathrm{C} 2$ & $1,{ }^{*} 1$ & 1 & 0 \\
\hline 7.3 & $6,{ }^{*} 2$ & $3,{ }^{*} 1$ & 0 & 1B1 & 1 & 0 & 0 & $4 \mathrm{C} 1$ & 3 & 3 & 0 \\
\hline 7.4 & 2 & 1 & 0 & 1B2 & 0 & 0 & 0 & $4 \mathrm{C} 2$ & $3,{ }^{*} 1$ & $4,{ }^{*} 1$ & 1 \\
\hline $8 \mathrm{~A} 1$ & 2 & 0 & 0 & $2 \mathrm{~A} 1$ & 1 & 1 & 0 & $4 \mathrm{C} 3$ & $2,{ }^{*} 1$ & 0 & 0 \\
\hline $8 \mathrm{~A} 2$ & 0 & 0 & $0,{ }^{*} 1$ & $2 \mathrm{~A} 2$ & 2 & 0 & 0 & $6 \mathrm{~A} 2$ & $1,{ }^{*} 1$ & 0 & 0 \\
\hline 8B1 & 1 & 1 & 0 & 2D1 & $3,{ }^{*} 4$ & 1 & 0 & $6 \mathrm{~A} 3$ & 2 & 6 & 0 \\
\hline 8B2 & $9,{ }^{*} 1$ & 0 & 0 & 2D2 & 5 & 1 & 0 & - & - & - & - \\
\hline 8B3 & $0,{ }^{* 1}$ & 0 & $0,{ }^{* 1}$ & - & - & - & - & - & - & - & - \\
\hline Total & $28,{ }^{*} 14$ & $6,{ }^{*} 1$ & $0,{ }^{*} 2$ & Total & $28,{ }^{*} 7$ & $11,{ }^{*} 1$ & $0,{ }^{*} 1$ & Total & $12,{ }^{*} 4$ & $14,{ }^{*} 1$ & 1 \\
\hline
\end{tabular}

* Bird was detected on survey run, but not at official observation point.

** Brown-headed Cowbird (BHC), White-eyed Vireo (WEV), and Black-throated Green Warbler (BTG). 
Table 8. List of nontarget species seen opportunistically on GCW and BCV surveys at Camp Bullis in 1997.

\begin{tabular}{|c|c|c|}
\hline SPECIES & SPECIES & SPECIES \\
\hline Turkey Vulture & White-eyed Vireo & Black-throated Green Warbler \\
\hline Black Vulture & Black-capped Vireo & Magnolia Warbler \\
\hline Northern Bobwhite & Red-eyed Vireo & Yellow Warbler \\
\hline Killdeer & Summer Tanager & Golden-cheeked Warbler \\
\hline Mourning Dove & Hermit Thrush & Nashville Warbler \\
\hline Inca Dove & American Robin & Black and White Warbler \\
\hline Ground Dove & Eastern Bluebird & Orange-crowned Warbler \\
\hline Yellow-billed Cuckoo & Roadrunner & American Redstart \\
\hline Chuck-will's Widow & Black-chinned & Great-tailed Grackle \\
\hline Common Nighthawk & Black-bellied Tree Duck & Brown-headed Cowbird \\
\hline Chimney Swift & Lesser Goldfinch & Red-winged Blackbird \\
\hline Scissor-tailed Flycatcher & American Goldfinch & European Starling \\
\hline Ash-throated Flycatcher & House Finch & Dickcissel \\
\hline Great-crested Flycatcher & Finch sp. & Blue Grosbeak \\
\hline Eastern Phoebe & Rufous-sided Towhee & Painting Bunting \\
\hline Western Kingbird & Great Blue Heron & Lark Sparrow \\
\hline Eastern Kingbird & Golden-fronted Wood & Grasshopper Sparrow \\
\hline Rough-winged Swallow & Ladder-backed & Field Sparrow \\
\hline Cliff Swallow & Blue-gray Gnatcatcher & Lincoln's Sparrow \\
\hline Barn Swallow & Eastern Screech Owl & Rufous-crowned Sparrow \\
\hline Purple Martin & Great Horned Owl & Northern Cardinal \\
\hline Scrub Jay & Red-shouldered Hawk & Chickadee (sp. not indicated) \\
\hline Common Raven & American Kestrel & Carolina Chickadee \\
\hline Tufted Titmouse & Red-tailed Hawk & Bewick's Wren \\
\hline Northern Mockingbird & Cooper's Hawk & Carolina Wren \\
\hline Swainsson's Thrush & Turkey & Cedar Waxwing \\
\hline
\end{tabular}

Ruby-crowned Kinglet 


\section{Discussion}

\section{Golden-cheeked Warbler}

Results suggest that the GCW population on Camp Bullis has been relatively constant in recent years. Overall, estimated density has changed very little since 1995. Although lower than in most previous years, the overall percent of occupied lines was constant in 1996 and 1997 at 66.7 percent (Table 2). In contrast to this, densities in 1996 and 1997 were higher than the 7-year average of 0.071 (Table 4). This suggests there may have been a tendency for a relatively greater concentration of GCW at occupied lines in 1996 and 1997 compared with most years. It is not known why this might be the case. It is not likely an artifact of the delayed field season in 1997 nor the number of times individual lines were run. That is, since there were more subpopulation lines in 1997 run only once compared with previous years, and since a second run would have allowed another opportunity to detect birds, once-run lines could have accounted for the majority of lines that did not have GCW in 1997. But that was not the case. Only two of the six once-run lines that were run in 1997 did not have GCW.

The late start of the 1997 field season had a threefold effect on the planning and completion of field work, thus affecting the quantity and types of the data that were obtained. First, it was unlikely that a full survey of the subpopulations (i.e., 2 runs at each of the 24 lines) could be completed. Second, GCW were nearer the middle of their breeding season when first runs were conducted. There may have been less distinction in breeding stages between first and second runs in 1997 compared to previous years. Third, there was less time and flexibility to schedule "make up" dates for lines affected by inclement weather. These effects underscore the importance of having field work begin as scheduled.

The results of density estimates and percent of lines occupied from the 1997 field season were notably similar to the 7-year average for each subpopulation. Lewis Valley had the highest percent of lines occupied over the course of 7 years and the highest in 1997, while Bullis Hills had the lowest. Lewis Valley supported the highest overall density and the highest in 1997. Similarly, Bullis Hills supported the least overall density and the least in 1997. Cibolo Creek supported densities moderate between the two subpopulations overall and in 
1997. Although there is some year-to-year variability, this overall trend suggests that each of the three subpopulations has some relatively stable elements resulting in this year-to-year constancy.

The estimated subpopulation densities from 1991 to 1997 suggest that Lewis Valley offers preferred habitat. Statistical review of the density estimates for the three subpopulations however, suggests that estimates may not differ greatly. Density estimate means of the three subpopulations were significantly different (ANOVA, $\mathrm{F}_{2,20}=7.06, \mathrm{p}=0.0055$ ), but Tukey's studentized range test for significance indicated that Lewis Valley and Bullis Hills were the only two sites that were significantly different from one another (at $p=0.05)$; means from Lewis Valley and Cibolo Creek, or from Cibolo Creek and Bullis Hills were not. It is the difference between Lewis Valley and Bullis Hills that accounts for much of the difference in the ANOVA. This is not to say that the means may not be biologically important, but only that one of the three comparisons was statistically so.

Two years, 1993 and 1995, are notable by their divergence from the 7-year averages. The lowest percent of "occupied lines" occurred in 1993, when 56.5 percent (Table 2) of the survey lines were reported to have GCW detections. It was also the year of the lowest installation-wide estimated density (0.048, Table 4). While the causes of this reduction are not known (it could have been the result of routine year-to-year variation, for example) it seems that it was related to greater variation in the Lewis Valley and Bullis Hills subpopulations. Both of these subpopulations experienced the greatest number of lines with no GCW detections in this year, while the number of lines at Cibolo Creek without GCW were relatively constant between 1991 and 1995 (0 to 2 lines annually without GCW detections). It is interesting however, that although GCW were detected on a similar number of lines in those years, the estimated density at Cibolo Creek dropped to its lowest point in 1993. Lewis Valley and Bullis Hills experienced the lowest of their estimated densities in 1993.

The year in which the highest percent of survey lines were occupied was 1995 when 87.5 percent of the survey lines had GCW. In this year, the explanation may have been related to effects at the Bullis Hills subpopulation. At both Cibolo Creek and Lewis Valley subpopulations, the number of lines lacking GCW was similar to numbers reported in most other years at the given subpopulation (except 1993). But 1995 was the only year in which there was at least one GCW detected on every survey line at Bullis Hills, and it is the year of the highest of the density estimates there as well. It was not however, the year of greatest density estimates for Cibolo Creek or Lewis Valley. 


\section{Black-capped Vireo}

The final count of $12 \mathrm{BCV}$ in 1997 is notably higher than the 6 verified in 1996 . And the count is somewhat conservative. There were likely other BCVs, such as the three mentioned in the result section that were not included in the total. The number documented in 1997 is a return to 1994 and years prior when it was routine to have 10 or more $\mathrm{BCV}$ documented annually.

This would appear to be a positive indication in population trends, but it is not clear if the 1997 total reflects a true population increase from 1995 and 1996. As mentioned, access to the live fire area was greater in 1997. This was probably the critical element of the BCV field season. Another possible reason for the increase is that field technicians searched areas not searched in recent years (e.g., Spoffard Hill) and found BCVs. Of course, all the access and searching would not have resulted in an increase if birds weren't located, so the BCV had to be present, at least in some numbers. Still, there is reason for caution for this interpretation. Some traditional sites appear to have become unoccupied in recent years, and that is a concern. Habitat at some locales appears to have grown beyond the successional stages preferred by BCV. It appears that management intervention is necessary to maintain and create habitat.

The fact that only one BCV was recorded at the Leon and Otis sites might be due to sparse searching there. Only two visits were made to that area, which is quite hilly and difficult to maneuver in. It likely would take more coverage to ascertain a more accurate read on BCV occupation there. Places like Hogan 1 and 2 for example, were visited at least six times. 


\section{Recommendations}

\section{General Recommendations}

The first general recommendation suggested in this report is to have a full-time, on-site, lead biologist to coordinate and supervise the field effort. This alone would resolve many logistical difficulties. An ornithological monitoring project of this nature typically requires several field biologists and a substantial amount of planning, scheduling, communication, and coordination. Projects such as these also have a substantial component of day-to-day decisions, rescheduling in the event of inclement weather or illness, and unpredictable events that occur. Again, these situations are best addressed by an on-site biologist who is prepared and can resolve such situations in the most efficient manner. Additionally, the presence of an on-site biologist ensures consistent field time by being able to take advantage of daily opportunities in access or scheduling.

A second general recommendation is that all related administrative processes be in place before March 15 each year so there is sufficient preparation time to train field biologists and begin the field season promptly.

Lastly, reference Rust and Wallace (1995) for a detailed management plan that addresses many aspects of endangered species research on Camp Bullis, including habitat management, military training, and bird monitoring.

\section{Golden-cheeked Warbler}

Stewardship Services has done an excellent job placing 60 survey lines throughout the installation that cover an area in excess of 9,000 ha. The first and last survey points on every line have been mapped with a Global Position System (GPS) unit. Most of these end points are marked (typically with flagging) and none of the interior points are marked. Biologists traditionally have been trained in orienteering and have successfully navigated these lines. It would be helpful however, particularly to surveyors who are not as comfortable with orienteering, or are new to Camp Bullis, to mark all observation points. Metal tags, flagging, painted marks on a tree, etc., have all been used in the past. Temporary marking, like flagging, would need to be replaced. One method 
of accomplishing this is to GPS every point and then mark them so that they are visible from a distance. Although this might require the full attention of a field biologist for a short period, it would save time during the survey by presenting obvious guidelines. Orienteering skills would still be necessary to get from point to point, but biologists would know if they were on track. If time is limiting, it is reasonable to map the points on the 24 subpopulation survey lines. Once points have been marked, it can then be determined if the collection of vegetation data at each observation point is still desired.

Although there are reasonable estimates of GCW abundance on Camp Bullis, there is no nesting or productivity data. Such data is critical in gauging the status of a population. Several accounts have shown that abundance data alone can lead to misleading interpretations about habitat quality (e.g., Van Horne 1983). While it may seem that areas with high densities are areas of higher quality habitat, that is not necessarily true. Simply put, more birds does not necessarily mean better habitat or better nesting conditions. It is well known that GCW nests are difficult to locate, and it may not be feasible to spend time searching for them. A reproductive index described by Vickery, Hunter, and Wells (1992) was developed to assess productivity for such birds. It is based on a regular territory monitoring regime. The index has been used successfully while studying GCW at Fort Hood, TX. Use of this index will provide an index to seasonal fecundity for GCW on Camp Bullis. The program could be established so that the three subpopulations are represented. Since GCW density estimates tend to be higher at Lewis Valley and lowest at Bullis Hills, it would be important to know if trends in fecundity parallel trends in density estimates. Data can then be entered into population models to help assess the status of the local subpopulations, and the entire population on Camp Bullis. This effort can require the full attention of a field biologist, but it is possible to incorporate this into the standard survey program.

If the GCW survey is going to focus on the 24 subpopulation lines in the future, a sample of the remaining lines should also be surveyed each year. A rotation should be developed in which approximately 5 to 10 additional lines are surveyed each year, so that after 5 years (if five or six additional lines are surveyed each year, for example) all of the remaining lines on the installation are surveyed. The additional lines to be surveyed should be chosen such that as much as possible of the remaining area is surveyed, dispersing them throughout the installation. 


\section{Black-capped Vireo}

It is recommended that the monitoring program for BCV be expanded to incorporate surveys wider in scope to allow visitation to new areas and closer scrutiny of nesting dynamics. To accomplish these ends, consistent access to vireo territories is required. The first five recommendations stated below are the most basic, and should be the first addressed if recommendations are prioritized. The sixth recognizes some areas to check for BCVs in 1998. The remaining recommendations would enhance our knowledge of $\mathrm{BCV}$, provide critical data required for population modeling, and support the monitoring effort.

1. It has been a number of years since there was a thorough installation-wide assessment of habitat for BCV. Brief investigations around the installation suggest there may be pockets of habitat of various sizes that may be usable. A case in point is the newly found BCVs on Spoffard Hill in 1997, which had not been searched in recent years. BCV habitat is ephemeral in nature and certain areas like fallow fields that are left unattended, or areas recently disturbed by fire or mechanical disturbance, can succeed into BCV habitat in 3 to 5 years. This installation-wide search for BCVs and available habitat may require the full attention of a field technician, or at least one working on this effort 50 percent of the field time. This search should occur a minimum of every 5 years, so that the entire installation is thoroughly inspected every 5 years. In other years, field personnel can focus on known habitat and investigate other areas if time permits.

2. Once territories are discovered, a standardized monitoring regime should be established to collect nesting data. At present, the only nesting data that is collected is opportunistic. In other parts of the range, BCV have proven to be vulnerable to cowbird parasitism. While anecdotal evidence at Camp Bullis does not suggest this phenomena is occurring, it needs to be investigated as there are BHC on Camp Bullis. There are also a number of other reasons to monitor the nesting activities more closely. Regular monitoring allows biologists to determine if males are mated. Often females can be inconspicuous and overlooked when only one or a few visits are made to a given territory. One of the most important pieces of data for fecundity measures is an accurate count of the number of fledglings that leave a nest. One way to obtain that information is to have visited the nest previously and having seen and aged the nestlings. On average, BCV nestlings fledge from the nest when they are 11 days old. By knowing the age of the nestlings, field personnel can be scheduled to revisit the nest on (or the day before) the fledgling date. Accurate fledgling counts will yield increased accuracy in seasonal fecundity estimates from which it can be determined if a population is producing an adequately sized pool of offspring. 
Monitoring can provide information on a number of nesting-related demographics like the degree of nest success, trends in nest predation pressure, and potential detriments to breeding success. Less critical to the basic needs, but as biologically important is that monitoring can provide information on nesting seasonality, favored nest substrates, favored microhabitats, etc.

It is expected that nest searching and discovery at Camp Bullis will occur as they have in other BCV monitoring programs. That is, given the opportunity, biologists will become quite adept at locating nests, which can be difficult for a novice to locate. If nest searching does go slowly, and an estimate of fecundity is needed immediately, the index described above for GCW could also be applied to $\mathrm{BCV}$. This index could also be used if nest monitoring is not opted for.

3. Since habitat is a limiting factor for BCV on Camp Bullis (and may be the limiting factor), intervention is called for to create and maintain habitat. Such intervention includes controlled fire and mechanical disturbance. Both have successfully been used elsewhere in central Texas to maintain BCV habitat or revert nonhabitat to BCV habitat. This need not, and should not occur at the expense of military training. With appropriate planning, effective management can, and has elsewhere, support both the military mission and the goals of the Endangered Species Act.

4. Territory borders and all BCV nests should be mapped with GPS equipment. The exact location of territories and nests is important, especially when examining nesting data in terms of vegetation or geologic data in a Geographic Information Systems (GIS) format.

5. Access to the live fire area improved greatly in 1997, due largely to the efforts of M. Sawyer and D. Pierantoni at Camp Bullis. Continued improvement would be to have increased access, but also access that is evenly distributed throughout the nesting season. May and June are months when this is particularly critical. If adequate territory and nest monitoring is to occur, visitation should occur at a given territory every 4 or 5 days, in addition to scheduling for critical nesting events (like fledgling described above in recommendation 2).

6. Some areas to check for BCV occupation in 1998 obviously include sites occupied in 1997, as well as the sites where the 5 potential occupants were. Sites occupied historically, like Sykes Hill or Otis Hill for example, but not in 1997 should also be checked (see previous reports like Stewardship Services 1991 through 1994; Stewardship Services 1995a, b; Thurber 1996). Areas such as Spoffard Hill and the south-southwestern hillside of the hill immediate northeast of Papke Hill (which is visible when viewed from Papke) that haven't 
been checked in recent years need to be surveyed. Installation-wide surveys as described in recommendation 1 , should be initiated to identify other potential habitat.

7. Consider initiating behavioral studies on BCV. BCV on Camp Bullis might represent a unique population. Although it has been suggested that BCV require a minimum threshold of $\mathrm{BCV}$ neighbors for successful nesting, the $\mathrm{BCV}$ on Camp Bullis are generally found in small numbers. It is also suggested that behavioral patterns reflect that increased level of isolation. For example, it is suggested there may be less singing and territorial defense than what occurs at large concentrations. Understanding why BCV on Camp Bullis exist in a more isolated system than other BCV provides greater insight and might support or dispel commonly held beliefs about BCV biology in general.

8. Consider initiating a banding program. A banding program can provide a great deal of information. Age structure, site fidelity, and nest and territory ownership all can be addressed with an effective banding program. Special interest here is also related to recommendation 4; a banding program would answer questions like whether local offspring are acquiring territories on Camp Bullis, or if territories are maintained by local adults, or if they are acquired by transients. Age and site fidelity data are critical pieces of information that are required in population viability models. Extreme caution is suggested before this recommendation is adopted however. There is always the potential of injury and unnecessary intrusion when banding. It is possible that some BCV might be negatively impacted, and that is an important consideration, particularly when dealing with populations as small as the one on Camp Bullis. For example, approximately 9 percent of the returning banded birds in one study of SW Willow Flycatchers had leg injuries (Sedgwick and Klus 1997). It was not known if the injuries were related to the banding experience, since there are also natural causes for the injuries. Banding can be informative, but injuries can happen. It should be considered ONLY if it addresses a research goal, and there is sufficient access and time to conduct it properly (e.g., identifying bands on birds when checking territories, and conducting searches in ensuing years to look for returning birds). 


\section{References}

Jetté, L. A., T. J. Hayden. J. D. Cornelius. Draft. Demographics of the Golden-cheeked Warbler (Dendroica chrysoparia) on Fort Hood, Texas. USACERL Technical Report 98/Draft.

Pulich, W. M. 1976. The Golden-cheeked Warbler. A Biogeographical Study. Texas Parks and Wildlife Department. 172 pp.

Rust, S. P., and S. A. Watson. 1995. A Natural Resources Management Planning Approach for Camp Bullis Military Training Reservation, Bexar County, Texas, San Antonio, TX.

Sedgwick, J. A., and R. J. Klus. 1997. Injury Due to Leg Bands in Willow Flycatchers. J. Field Ornithology 68(4):622-629.

Stewardship Services. 1991. 1991 Field Season Report. Endangered Bird Survey on Camp Bullis Training Reservation, Fort Sam Houston, Texas. Report prepared for U.S. Army Construction Engineering Research Laboratory. Champaign, IL.

Stewardship Services. 1992. 1992 Field Season Report. Endangered Bird Survey on Camp Bullis Training Reservation, Fort Sam Houston, Texas. Report prepared for U.S. Army Construction Engineering Research Laboratory. Champaign, IL.

Stewardship Services. 1993. 1993 Field Season Report. Endangered Bird Survey on Camp Bullis Training Reservation, Fort Sam Houston, Texas. Report prepared for U.S. Army Construction Engineering Research Laboratory. Champaign, IL.

Stewardship Services. 1994. 1994 Field Season Report. Endangered Bird Survey on Camp Bullis Training Reservation, Fort Sam Houston, Texas. Report prepared for U.S. Army Construction Engineering Research Laboratory. Champaign, IL.

Stewardship Services. 1995a. 1995 Field Season Report. Endangered Bird Survey on Camp Bullis Training Reservation, Fort Sam Houston, Texas. Report prepared for U.S. Army Construction Engineering Research Laboratory. Champaign, IL.

Stewardship Services. 1995b. Camp Bullis Training Materials. Endangered Bird Sampling/Monitoring.

Tazik, D. J. 1991. Proactive management of an endangered species on Army lands: The Blackcapped Vireo on the lands of Fort Hood, Texas. Ph.D. thesis. University of Illinois, Urbana. 247 pp.

Thurber, D. K. 1996. 1996 Field Season Report. Endangered Bird Survey on Camp Bullis Training Reservation, Fort Sam Houston, Texas. 
U.S. Fish and Wildlife Service. 1987. Endangered and Threatened Wildlife and Plants; Determination of the Black-capped Vireo to be an Endangered Species (USFWS). Federal Register, Vol. 52, No. 193.

USFWS. 1990. Endangered and Threatened Wildlife and Plants; Emergency Rule and Proposed Rule to List the Golden-cheeked Warbler as Endangered. Federal Register 50 CFR Part 17.

Van Horne, B. 1993. Density as a misleading indicator of habitat quality. J. Wildl. Mgt. 47:893901.

Vickery, P. D., M. L. Hunter, Jr., and J. V. Wells. 1992. Use of a new reproductive index to evaluate relationship between habitat quality and breeding success. Auk 109(4):697-705. 